\title{
A Manuscript of the Mongolian Folk Tale "About Old Borontai" from the IOM, RAS Collection
}

Abstract: The manuscript "About Old Borontai" kept in IOM, RAS, is one of the earliest written fixations of the cumulative tale common among Mongolian people and well known to scholars working in the field. The present paper contains the first ever publication of the manuscript in transcription and translation of the text written in old Mongolian script based on the Uighur alphabet.

Key words: Mongolian manuscripts, lore, folklore, tales, cumulative tales

The three items at the Mongolian manuscripts and xylographs fund of IOM, RAS containing Mongolian tales originated from different collections, one belonging to A.M. Pozdneev (1851-1920), another to the Kazan Theological Academy (hereafter, KDA) and the third to D. A. Alekseev. ${ }^{1}$ They all arrived in Petrograd/Leningrad between 1920 and 1947. All of them have remained unpublished until now; therefore, introducing them to scholars will significantly broaden our perception of the topics and poetics of 19th20th cc. Mongolian oral folklore.

The manuscript chosen for publication here is written in old Mongolian script and kept in the Mongolian collection of the IOM, RAS Manuscript Department (des. D 114). The two unseparated folios of Russian bluish paper each measure $17.5 \times 21.5 \mathrm{~cm}$; the text occupies three sides written in pen and black ink. The maximum number of lines on a page is $18 .^{2}$

\footnotetext{
(C) Dmitrii Nosov, Institute of Oriental Manuscripts, Russian Academy of Sciences

${ }^{1}$ Dmitrii Adrianovich Alekseev was a Soviet philologist specializing in Mongolian. In 1938-40, a post-graduate student at the Institute of Oriental Studies (Leningrad), in 1945-48, a doctoral student of the IOS and a professor at Leningrad State University, from 1949 Head of the Mongolian department within its Oriental Faculty. His collection of 13 items was received by the Institute in 1947 (SAZYKIN 1988, 16-17).

${ }^{2}$ SAZYKIN 1988, 45.
} 
The manuscript has inventory marks from 1929 and 1962. Its 1929 designation - KDA $328^{3}$ - indicates that it once belonged to the large collection delivered to the Asiatic Museum in 1927-28 from the disbanded KDA.

The manuscript bears no title, but its contents can be deduced from its first line. That was the way in which it was described by A.G. Sazykin (19432005) in his catalogue of Mongolian manuscripts and xylographs: "erte čagtu nige borontai ebügen geji yabuba". ${ }^{4}$ This standard beginning of a Mongolian tale should be translated as "Once upon a time there lived an old man called Borontai". Regrettably, IOM did not receive from Kazan any descriptions accompanying the texts, so the precise dating of the manuscript and the place where it was written remain obscure.

The folktale type, presented by the manuscript, was listed as No. 198 at the catalogue, compiled by Laszlo Lörincz. The type was named Die Heldentaten des Alten, der nie existierte [The exploits of an old man, who never existed] and seen as unique, having no similarities among other peoples' folklore ${ }^{5}$. It includes two publications in Russian, made by M.N. Khangalov (1858-1918) in 1889 and by G.N. Potanin (1835-1920) in 1893. And two publications in Mongolian, made in late 1950-es. ${ }^{6}$

Mongolian texts were later united ${ }^{7}$ under the title "Old man Borolzoi who never existed" by D. Tzerensodnom, a researcher who assembled a scholarly collection of Mongolian lore. He defined it as a heroic fairy tale. ${ }^{8}$ However, the structure of the composition shows that it should rather be considered a cumulative epic tale, according to V.Ia. Propp's (1895-1970) classification. ${ }^{9}$

The structure of this composition is unique; it seems to consist of two cumulations. In the first part, the hero keeps being attacked by enemies of increasing strength, but his abilities allow him to defeat them all. Later, the hero and Khormusta-tengri ${ }^{10}$ have a talk during which the hero consistently rejects all charges. Below is a summary of the plot as presented in Tzerensodnom's publication:

\footnotetext{
${ }^{3}$ SAZYKIN 1988, 45.

${ }^{4}$ SAZYKIN 1988, 45.

${ }^{5}$ LÖRINCZ 1979, 111.

${ }^{6}$ LÖRINCZ 1979, 111.

${ }^{7}$ Mongol ardyn ulger $<$ Монгол ардын үлгэр $>1982,334$.

${ }^{8}$ Mongol ardyn ulger $<$ Монгол ардын үлгэр $>1982,81-83$.

${ }^{9}$ PROPP 1976, 244.

${ }^{10}$ Khormusta-tengri in Mongolian folklore is the supreme god, the ruler of the world.
} 
One of old Borolzoy's sheep gives birth to a snow-white lamb that the owner decides to sacrifice to Khormusta-tengri $\|$ : Khormusta-tengri's raven pecks out the lamb's eyes. In revenge, Borolzoy tears the raven's beak off. Khormusta-tengri sends wolves to kill Borolzoy's gray flying horse, but Borolzoy replaces the flying horse with a regular one and pulls the wolves' hides over their heads. Then, Khormusta-tengri sends two demons to assassinate the old man, but the intended victim burns their faces. Khormustatengri dispatches two dragons to turn the old man into ashes, but Borolzoy hides from them, and then catches them and chops their tails off. : $\|$ Khormusta-tengri decides to discuss the issue with the old man himself. The man comes to his dwelling and Khormusta-tengri starts questioning him. $\|$ : Why did he pull the raven's beak off? Why did he pull the wolves' hides over their heads? Why did he burn the two demons' faces? Why did he chop the dragons' tails off? The old man gives consistent and satisfactory answers. : $\|$ Khormusta-tengri lets him go. ${ }^{11}$

In brief, the text of manuscript D 114 tells the story like this:

One of old Borontai's sheep gives birth to a snow-white lamb that the owner decides to sacrifice to Khormusta-tengri $\|$ : Khormusta-tengri's two ravens peck out the lamb's eyes. In revenge, Borontai tears the ravens' beaks off. Khormusta-tengri sends two wolves who kill Borontai's poor gray horse, and Borontai pulls the wolves' hides over their heads. Khormustatengri sends his seven devils who tear away a wall of the old man's yurt; the man puts out their eyes in revenge. Khormusta-tengri sends Tengri ${ }^{12}$ the Thunderer who burns the hill on which the old man lives, and Borontai takes his revenge by chopping through the calf of his leg. : $\|$ Khormusta-tengri then decides to see the man himself. The old man greets him and Khormustatengri starts his questioning. $\|$ : Why did he pull the ravens' beaks off? Why did he pull the wolves' hides over their heads? Why did he put out the seven devils' eyes? Why did he chop through Tengri the Thunderer's calf? The old man gives consistent answers which satisfy Khormusta-tengri. :\| Then Khormusta-tengri gives old Borontai wealth and a lot of children.

The tale about old Borontai was known not only among the Mongols, but among the Buriats as well. It was written down by M.N. Khangalov while

\footnotetext{
${ }^{11}$ Here, the cumulation is placed between the repetition signs $\|::\|$ which Propp borrowed from music notation (PROPP 1976, 249).

${ }^{12}$ Tengri was a god of Mongolian lore.
} 
visiting Balagan Buryats ${ }^{13}$ near Irkutsk. That text has been published three times: in the collected "Buryat tales" in "VSORGO notes on ethnography" (Irkutsk, 1889) ${ }^{14}$ in the collected works of that scholar where it was listed among Shamanic legends, ${ }^{15}$ and in a collection of Buryat folklore published in $1990 .{ }^{16}$ The plot of that version is as follows:

Two ravens peck out old Khoredoy's lamb's eyes. $\|$ : He tears one eye from each of them and gives them to his lamb. The ravens complain to Esege-malan. ${ }^{17}$ Wolves kill a limping stallion, and the old man skins them. The wolves complain to Esege-malan. The old man pours boiling water over nine shulmuses. ${ }^{18}$ The shulmuses complain to Esege-malan. : $\|$ Esege-malan comes to old Khoredoy and asks him, why he $\|:$ tore out the ravens' eyes, skinned the wolves, and burned the shulmuses. :\| The old man explains the situation. Esege-malan, satisfied with the answers, leaves him in peace.

This tale is peculiar, as it has a type of cumulation missing from those found in Russian folklore and therefore from Propp's morphological descriptions. The present manuscript is possibly the earliest Mongolian fixations of the tale type Die Heldentaten des Alten, der nie existierte [The exploits of an old man, who never existed], since it came to Kazan no later, than $1920 .{ }^{19}$

Below, are the transcription and translation of the manuscript.

\section{Transcription of manuscript D 114}

\section{Folio 1a:}

[1] erte čag-tu nige borontai ebügen geǰi yabuba. Tere sayin boru

[2] mori mayu boru mori qoyar-tai : 10 boru qoni agsan ajı

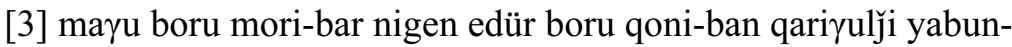

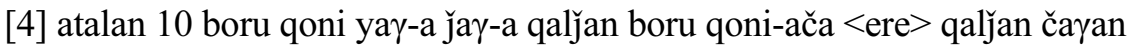

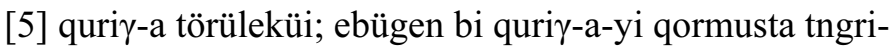

${ }^{13}$ Balagan Buryats belong to the Balagan or Ungin local ethnic groups dwelling in the valleys of the Unga and its tributaries, along the middle Oka, and the western bank of the Angara (The Buryats 2004, 50). That area presently belongs to Irkutsk region of Russian Federation.

${ }^{14}$ Khangalov $1889,4-6$.

${ }^{15}$ Khangalov 1960, 35-37.

${ }^{16}$ Buryat Fairy Tales 1990, 65-66.

${ }^{17}$ Esege-malan was a senior deity of Buryat lore.

${ }^{18}$ A shulmus (in this context) was "a devil, a demon".

${ }^{19}$ USPENSKII 1994, 16. 
[6] degen ergümüi kemen yekede bayarlaji : busu qoni-ban bučayuqui-yin

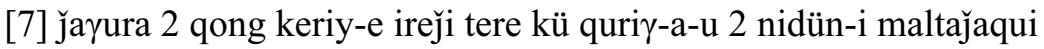

[8] ebügen tegüni üǰeged maši yeke qumuduju : juigürten-i güyčeden[ $=\mathrm{g}]$

[9] sayin boru mori-ban unujuu tere kü 2 qong keriy-e-yi bariǰu nidün-i

[10] maltatai amitui tabiba : tere kü 2 keriy-e anu qormasta tngri-dür

[11] očini ebügen-i mörgübei : qormasta tngri 2 činu-yi borontai ebügen-ü

[12] jigürten-i güyčedeg sayin boru mori-yi idegtün kemen jakiji ilegebei

[13] ebügen 2 činu-a ireǰi sayin boru mori-yi ideküi-i jöng bilig-iyer

[14] medeged : sayin boru mori barilyadaq yajar-a mayu boru mori-ban

[15] bayilyaǰi : sayin boru mori yadan-a tabiba 2 činu süni ireǰi

[16] maүu boru mori-yi idesüküi : ebügen sayin boru mori-bar 2 činu-a-yi

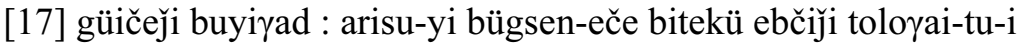

[18] toryuj̆i amitui tabčuqui : 2 činu-a qormasta tngri-yi očiju

\section{Folio 1b:}

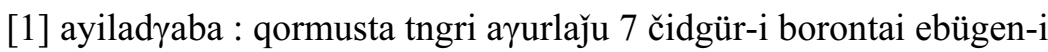

[2] alaytun kemen ǰakiǰi iledkebe : ebügen mön tede-i ireküi-yi medeged :

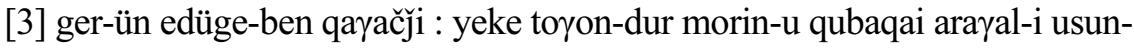

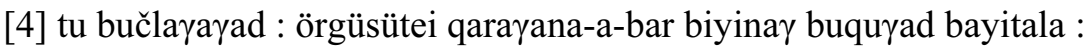

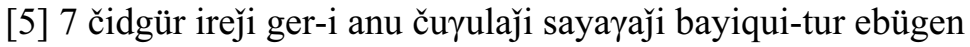

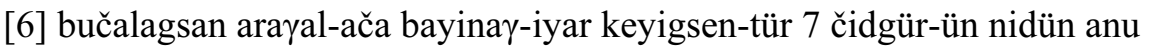

[7] tasqurba gekü : tede mön qurmasta-dayan ayiladqaysan-tu : buri

[8] yeke aqurlaju : nirgeden tngri-yi borontai ebügen-i nirgi kemen

[9] jakiǰi ilegebi : borontai ebügen tegün-i medeged : sayin mori-ban

[10] unuǰi sayaday umar-ban angsaǰi : sarun čayin selmen-ben ǰegüjü

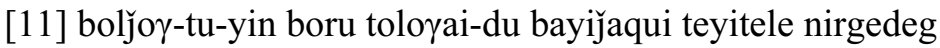

[12] tngri ireǰi nirgeküi-dür sayin boru mori-bar deb geji qarqui-dur

[13] boru toloyai-yin kemke nirgejüküi : nirgede tngri-yin gün-ün

[14] bolčin-i borontai ebügen selmen-ber tasu čabčiji gemüi nirgedeg

[15] tngri anu mön qormusta tngri-du ayiladqaba qormusta anu

[16] bi über-e üǰǰi tegün-ü jöb buruүu-yi šigüsügei geküi-yi ebügen

[17] medeged 10 boru qoni <illegible> yay-a jay-a qaljan borulan qoni alaju

[18] čeberken bolyuji čaqan tuluq debsger debsün : eldeb idegen

\section{Folio 2a:}

[1] amtan-u degeǰi beledüged qurmasta tngri ireǰi mini jadqaүlal

[2] soyurqa kemen jalbarin mörgüji bayital-a qormasta irgeged : ǰ-a ebügen

[3] 2 keriy-e-ü mini nidün yayun-tu maltaba gebe : qormasta tngri-tan dayan 
[4] bariqu kemen bayarlaǰi bayigsan qaljan čayan quriyan-u mini nidün maltaysan-

[5] du qumuduyad maltalai bi gebe : tere činu jöb : 2 činu-ǰ-u arasu-yi

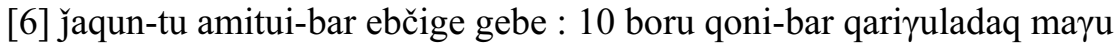

[7] boru mori-yi-ban idegsen-dü yomuduji tegsleb bi gebe : tere čini jöb :

[8] 7 čidgür-ün nidü-yi yayun-du tasulaba gebe : namayi-yi alaqu-bar $<$ illegible>

[9] alan ügei em ür-e-yin mini toloqai-ban qayaǰi sayuqu ger-i

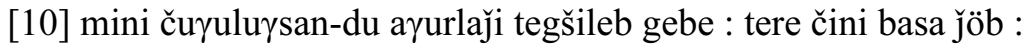

[11] nirgeden tngri-yin bolčin yayun-du tasu čabčiba gebe : namai-yi

[12] nirgen ügei 10 boru qoni-u mini iredeq boru toluyai nirgegsen-tü tegsleb

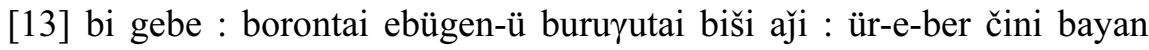
önör

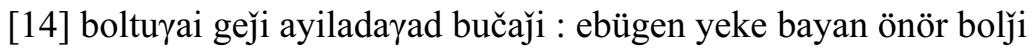

[15] jaryaba gekü :

\section{Translation of manuscript D 114}

Once upon a time there lived an old man called Borontai. He had a good gray horse, a poor gray horse, [and] 10 gray sheep. Once, while the old man was riding his poor gray horse and shepherding his ten gray sheep, a dappled white sheep with a white muzzle gave birth to a snow-white lamb. The old man was happy and said,

"I will sacrifice this lamb to my Khormusta-tengri."

On his way back home, two ravens appeared that plucked out the lamb's eyes. The old man, seeing this, got enraged, mounted his good gray horse which could outrun birds, caught the ravens, plucked out their eyes, and let them go. The two ravens flew to Khormusta [and] complained about the man. Khormusta-tengri sent two wolves telling [them], "Feed on old Borontai's good gray horse which outruns birds". The old man sensed the wolves coming to feed on his good gray horse and left his poor gray horse in the place where his good gray horse used to be kept, leaving his good gray horse outside. At night, the two wolves came and ate the poor gray horse. In the morning, the old man mounted his good gray horse, caught the two wolves and skinned [their] behinds. Then, after stitching the hides to their heads, he let them go. The two wolves went to Khormusta-tengri to tell [him about 
everything]. Khormusta-tengri, angered, sent seven devils with the order to dispatch old Borontai. Having learned about them coming, the old man locked the door of his yurt [and] began coiling dry horse $\operatorname{argal}^{20}$ in a large caldron stirring it with a thorny stick of caragana. ${ }^{21}$ When the seven devils came and began watching through [a hole in the wall] of his yurt, the old man hit [them] with the stick taking it out from the argal boiling [in the caldron]. Thus he pierced the eyes of the seven devils, so people say. When they reported back to Khormusta, too, he got even angrier and sent Tengri the Thunderer with orders to kill old Borontai with a lightning bolt. Old Borontai heard about that, saddled his good horse, took his coral sword and rode northwards. After Tengri the Thunderer turned into ashes everything on that gray hill, [the old man] immediately came back on his good gray horse and chopped Tengri the Thunderer's calf through to the bone for having completely burnt the gray hill, so people say. Tengri the Thunderer also reported everything to Khormusta. When the old man learned that Khormusta said,

"I will go myself and see if this is true or not".

Then he <illegible> his ten gray sheep, slaughtered his dappled white sheep with the white muzzle, spread a clean white carpet, cooked various best dishes, and prayed saying,

"May you arrive, Khormusta-tengri, may you arrive".

Khormusta-tengri arrived and [asked],

"Well, old man, why did you pluck out the eyes of my two ravens?"

"Khormusta-tengri, after they pecked out the eyes of my gray lamb with a white muzzle that I had intended to sacrifice to you, [I] felt insulted, so I plucked their eyes out".

"You had the right to do that".

"But why did you skin the two wolves alive?" [Khormusta-tengri] asked.

"After they had fed upon my poor gray horse on which I shepherded my ten gray sheep, I got angry and took my revenge", [old Borontai] said.

"You had the right to do that, too".

"When they tried to kill me, but failed, having beheaded my wife and children, when they cut the wall of my yurt in which [I] was sitting, hiding my head, [I] was enraged and [thus] took my revenge", he said.

"Again, you had every right to do that".

\footnotetext{
${ }^{20}$ Argal is dried manure used as fuel in Mongolia.

${ }^{21}$ Caragana (Lat. Caragána) is a species of leguminous plant.
} 
"Why did you, then, chop through the calf of Tengri the Thunderer?" he asked.

"That was my revenge," [he] said, "for his having struck the gray hill on which my ten gray sheep grazed, when he had failed to kill me with his lightning".

"Old Borontai is not guilty of anything. May you be wealthy and have many children". Having said this, he went away.

The old man became rich, had many children, and lived happily ever after, [so] they say.

\section{References}

Buriatskie narodnye skazki 1990: Buriatskie narodnye skazki [Buryat Fairy Tales]. Moscow: Sovremennik.

Buriatskie skazki i pover'ia 1889: "Buriatskie skazki i pover'ia, sobrannye N.M. Khangalovym, N. Zatopliaevym i drugimi" [Buryat Fairy Tales and Popular Beliefs collected by N.M. Khangalov, N. Zatopliaev, and others]. In: Zapiski Vostotchno-Sibirskogo Otdela Imperatorskogo russkogo geograficheskogo obshchestva [Notes of Eastern Siberian Department of Russian Imperial Geographic Society], vol. I, issue 1. Irkutsk: Na sredstva Chl. A.O. Startseva.

Buriaty 2004: Buriaty [The Buryats]. Moscow: Nauka.

Khangalov M.N. 1960: Sobranie sochinenii [Collected works], vol. III. Ulan-Ude: Buriat kn. Izd-vo.

LöRINCZ L. 1979: Mongolishe Märchentypen. Budapest: Akademiai KIADO.

Mongol ardyn ulger 1982: Mongol ardyn ulger. D. Tzerensodnom emkhtgev [Mongolian folktales. Collected by $D$. Tzerensodnom]. Ulaanbaatar.

PROPP V.Ia. 1976: Fol'klor i deistvitel'nost'. Izbrannye stat'i [Folklore and reality. Selected works]. Moscow: Nauka.

SAZYKIN A.G. 1988: Katalog mongol'skikh rukopisei i ksilografov Instituta vostokovedeniia Akademii Nauk SSSR [Catalogue of Mongolian manuscripts and xylographs kept at the Institute of Oriental Studies of the USSR Academy of Sciences], vol. I. Moscow: Nauka.

USPENSKII V.L. 1994: "Mongolovedenie v Kazanskoi Dukhovnoi Akademii" [Mongol studies at the Kazan Theological Academy]. Mongolica III. St. Petersburg: Nauka, 11-17. 